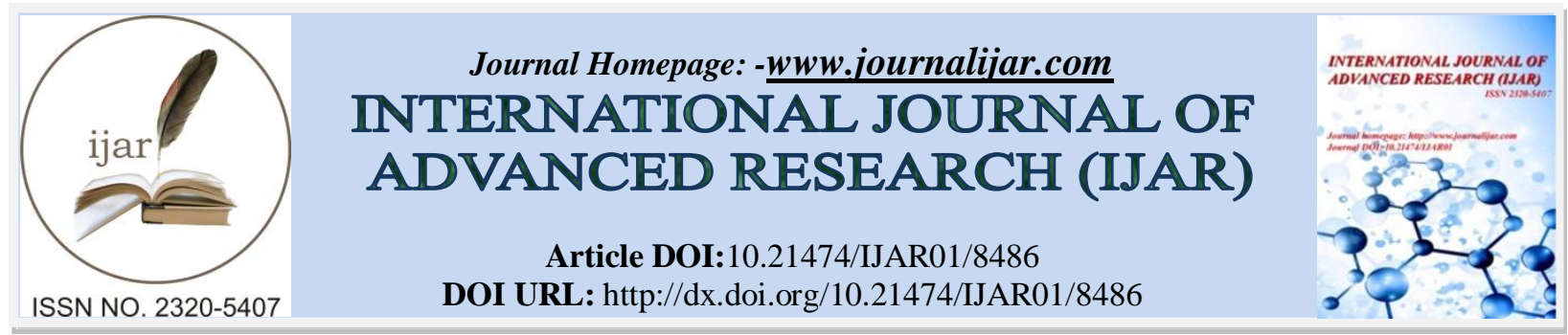

RESEARCH ARTICLE

\title{
MIX-MARKETING STRATEGY IN INCREASING THE NUMBER OF TOURISTS IN JAYA ANCOL ART MARKET.
}

\author{
Rahayu. \\ University of Prof. Dr. Moestopo (B) Jakarta,Indonesia.
}

\section{Manuscript Info}

\section{Manuscript History}

Received: 04 December 2018

Final Accepted: 06 January 2019

Published: February 2019

Key words:-

Atmosphere, Promotion , Brand Image

, Tourist Satisfaction, The Increasing

Number of Tourists.

\begin{abstract}
To increase the number of visitors coming to Jaya Ancol Art Market, the management of PT Jaya Ancol uses the mix marketing strategy. The objectives of this study is to answer the study hypotheses which are: (1) The atmosphere influence toward the increasing number of tourists in Jaya Ancol Art Market (2) The influence of promotion toward the increasing number of tourists in Jaya Ancol Art Market (3) The influence of brand image toward the increasing number of tourists in Jaya Ancol Art Market (4) The influence of tourist satisfaction toward the increasing number of tourists in Jaya Ancol Art Market.

In this study, the research method uses verificative and descriptive research,and data collection uses survey method with 243 tourists of Jaya Ancol Art Market Jakarta, Indonesia as the sample by using purpose sampling technique and to answer the hypotheses analysis tool used is Structural Equation Model by using listrel software.

The result of descriptive analysis by using average score shows not only positive but also negative result. The test result of four hypotheses using SEM analysis tool shows positive result that is (1) The park atmosphere influences significantly the increasing number of tourist visit in Art Market Jaya Ancol, (2) Promotion significantly influences the increasing number of tourist visit in Art Market Jaya Ancol, (3) Brand image significantly influences the increasing number of tourist visit in Art Market Jaya Ancol, (4) Tourist satisfaction significantly influences the increasing number of tourist visit in Art Market Jaya Ancol.
\end{abstract}

Copy Right, IJAR, 2019,. All rights reserved.

\section{Introduction:-}

In this millenial era, local and international tourists like to look places for them to hang out such as café, eating places and amusement park. Those three tourist spots are available in Art Market Jaya Ancol even though the facilities have not been fully maximized.

Jaya Ancol Art Market is located in the tourism area of Jaya Ancol. It is the place where the painters sell their paintings. It is also fuctioned as tourist spot. The paintings area is located in the front part of the market. Next to it, there is a place for tourist enjoying some drinks but it is still a semi-restaurant. The place offers not only some drinks but also some traditional food. While enjoying the drinks and food, tourists can sit in front of the restaurant

Corresponding Author:-Rahayu.

Address:-University of Prof. Dr. Moestopo (B) Jakarta,Indonesia. 
under the trees and feel the zephyr while listening to some music. Wakefield and Baker [39] proved that customers prolong their stay because of the atmosphere stimulus. Atmospehere stimulus of Jaya Ancol Art Market is the restaurant attraction of music played such as jazz, dangdut, pop with heart-pleasing ambiance. [20]

Art market has ever become a famous amusement park in the 1980s. There were many local tourists visited it almost every day. At that time it became the place for young people to hang out, enjoy the paintings and the music. It became the art icon of the capital city. Along the way, art market has been replaced by other places.

In 2018, Jaya Ancol Art Market celebrates its 40th anniversary. The assets management PT Jaya Ancol started to develop the art market asset. Every weekend, art market shows live music. Every Friday, Saturday and Sunday, there is a small scale music concert. The music genre is different each day. On Fridays, it is jazz, while on Saturdays it is pop and Sundays with reggae [22]

Promotion is needed in introducing the product. Several studies mention that customers respond the selling promotion because it has positive benefit for them [8]. To increase the sale, promotion is needed as the key to product differenciation [29]. Sale promotion of the study result proves that it influences brand loyalty [9]; [10]; [23];[3]. Study approach done by Luk and Yip [23] explains that large scale promotion tends to impact the brand loyalty. Promotion is a company action to communicate product benefit and as the tool to influence consumers in service purchasing activity[6].

The characteristics of art market now can be described as café, park, music band and paintings that can be created as brand. These specific characteristics emotionally impact return purchase [20]. The customers who feel satisfied with the art market will love to spend time there and will come over and over again [4].

Based on this pre-study and the previous study supporting this research, the title of this study is "Mix-Marketing Strategy in Increasing the Number of Tourists in Jaya Ancol Art Market”.

\section{Identification and Study Framework}

Based of the problem identification, the literature review “ The influence of Atmosphere ,Promotion ,Brand image andTourist satisfaction toward The increasing number of tourists in Jaya Ancol Art Market.

1. Is there any influence on theatmosphere to the increasing number of tourists in Jaya Ancol Art Market ?

2. Is there any influence on thepromotion to the increasing number of tourists in Jaya Ancol Art Market?

3. Is there any influence on the brand image to the increasing number of tourists in Jaya Ancol Art Market ?

4. Is there any influence on the tourist satisfaction to the increasing number of tourists in Jaya Ancol Art Market?

\section{Literature}

\section{Tourist Increasaing}

Tourists increasing is where tourists have visited for several times or tourist loyalty. Shiffman and Kanuk [36] found the same consumer behavior increases in visiting the same object. According to Gommans [13] the commitment of consumer after purchasing the product and will purchase again and will never switch to other company. Consumer recommends to other people to visit the art market [5].

The indicators of tourist increasing used in this research is increasing visit frequency, revisit commitment and recommending to other people.

\section{Park Atmosphere}

Wakefield and Baker [39] park atmosphere is an interesting park situation such as painting store, great restaurant, shady trees, cool zephyr, wide field and music. Abednego [2] states that restaurant atmosphere makes emotional intention to buy. Bohl [4] proves that the customers who linger in the restaurant increase because of the restaurant atmosphere.

Indicators of park atmosphere used in this study are park situation, emotional and linger [39]; [2]; [4].

\section{Promotion}

Promotion is the key to product differentiation [29], the more frequent advertisement shows the more expensive promotion expense the more superior the product from the other ones [21]. Promotion effectively builds association brand [30]. 
Indicators of promotion used in this research are product differentiation, advertisement frequency, association brand $[29] ;[21] ;[30]$.

\section{Brand Image}

Brand image is an assumption of a brand thoroughly on the image of a company that is stayed in the consumer's mind. The company brand image is the whole image like brand image attribute image benefit and image attitude [1]; [29].

Brand image indicators used in this research are attribute, benefit and reputation [1]; [29;[8].

\section{TourisStatisfaction}

Bosilie et al [2] states that tourist satisfaction is the definition shows how many good stuffs, maintenance, service and approaches to be able to meet the customer expectation. Satisfied customer is happy customers, customers that get complete benefits that meet their expectation and hopes [26].

Indicators of tourists satisfaction used in this research are product quality, service quality, price and easiness [38]; [27].

\section{Hypotheses}

The influence on atmosphere to the increasing number of tourists

H1: There is a positive influence on atmosphere to the increasing number of tourists

The influence on promotion to the increasing number of tourists

$\mathrm{H} 2$ : There is a positive influence on promotion to the increasing number of tourists

The influence on brand image to the increasing number of tourists

H3: There is a positive influence on brand image to the increasing number of tourists

Theinfluence ontourist satisfaction to the increasing number of tourists

$\mathrm{H} 4$ :There is a positiveinfluence on tourist satisfaction to the increasing number of tourists

\section{Study Consept}

In accordance with study context, study conceptual model then being that are influence of Atmosphere ,Promotion ,Brand image and Tourist satisfaction toward The increasing number of tourists in Jaya Ancol Art MarketFigure 1.

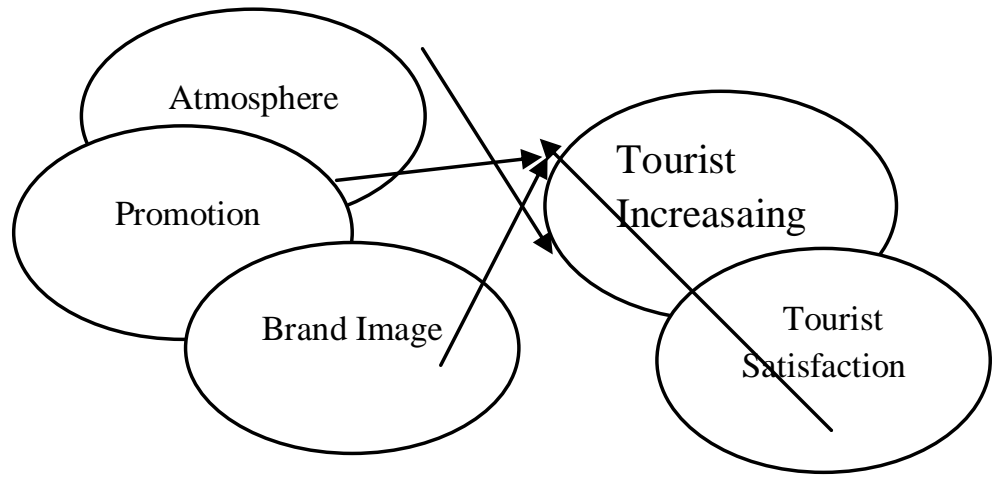

Figure 1:-Model KonseptualPenelitian

\section{Study Methodology:-}

This research designs are verificative and descriptive research by using survey method [18] in qualitative and quantitative methods form [18]. Data collecting uses questionnaire by asking a set of questions to respondents using linker scale $1-5$ ( Sugiono ,2009), sampling technique used is purpose sampling [37] that is tourists that have visited the park several times are 245 respondents of tourists in art market [15] Jakarta, Indonesia. Before starting the field task, there was questionnaire test spread out for 30 tourists in the art market. It was done to complete validity and reliability instrument used in this study [33]. 
Analysis tool used for the research variables uses statistics percentage average and inter-variable influence analysis uses Structural Equation Model ( SEM) andlisrel 8.8. [34].

\section{Study ResultandDisscustion}

\section{Descriptive Statistics}

The average analysis result shows that the respondents consider the atmosphere, promotion, brand image and tourist increasing are still not good, while the evaluation on satisfaction and tourist increasing is good.

\section{Inter-variable influence analysis}

Model suitability index can be seen in Table 1.

The result of model accuracy test from 8 index 1 marginal fit (GFI) and 7 is into good fit category (RMSA,RMR,AGFI,NFI,IFI,RIF). Model suitability index is mostly into fit category. It can be concluded that emphirical model of service quality, customer satisfaction, words of mouth toward loyalty fit with the theoritical model [16].

Table 1:-Model Suitability Testing

\begin{tabular}{|l|l|l|l|}
\hline No & \multicolumn{1}{|c|}{ Expexted size } & Estimated results & \multicolumn{1}{|c|}{ Match level } \\
\hline & Absolut size fit & & \\
\hline 1. & $R M S A<0,80$ & $R M S A=0,077$ & Good Fit \\
2. & $R M R<0.1 \quad$ Site of incrementalfit & & \\
\hline & \multicolumn{1}{|c|}{ Good Fit } & \\
\hline 3 & GFI $>0,90$ & GFI $=0.88$ & Marginal Fit \\
4 & AGFI $>0,90$ & AGFI $=0,92$ & Good Fit \\
5 & NFI $>0,90$ & NFI $=0,97$ & Good Fit \\
6 & CFI $>0,90$ & CFI $=0,93$ & Good Fit \\
7 & IFI $>0,90$ & IFI $=0,95$ & Good Fit \\
8 & RIF $>0,90$ & RIF $=0,97$ & Good Fit \\
& & & \\
\hline
\end{tabular}

Source: computer analysis output (2018)

Computer output regarding the influence of atmosphere, park, promotion, image and satisfaction toward tourist increasing in Jaya Ancol Art Market shows the result of t count value factor loading is higher than critical value $(1,96)$, factor loading $>0,50$ [16] and factor loading $>30$ ( Igbrain Hair) [16] shows that variable is significant.

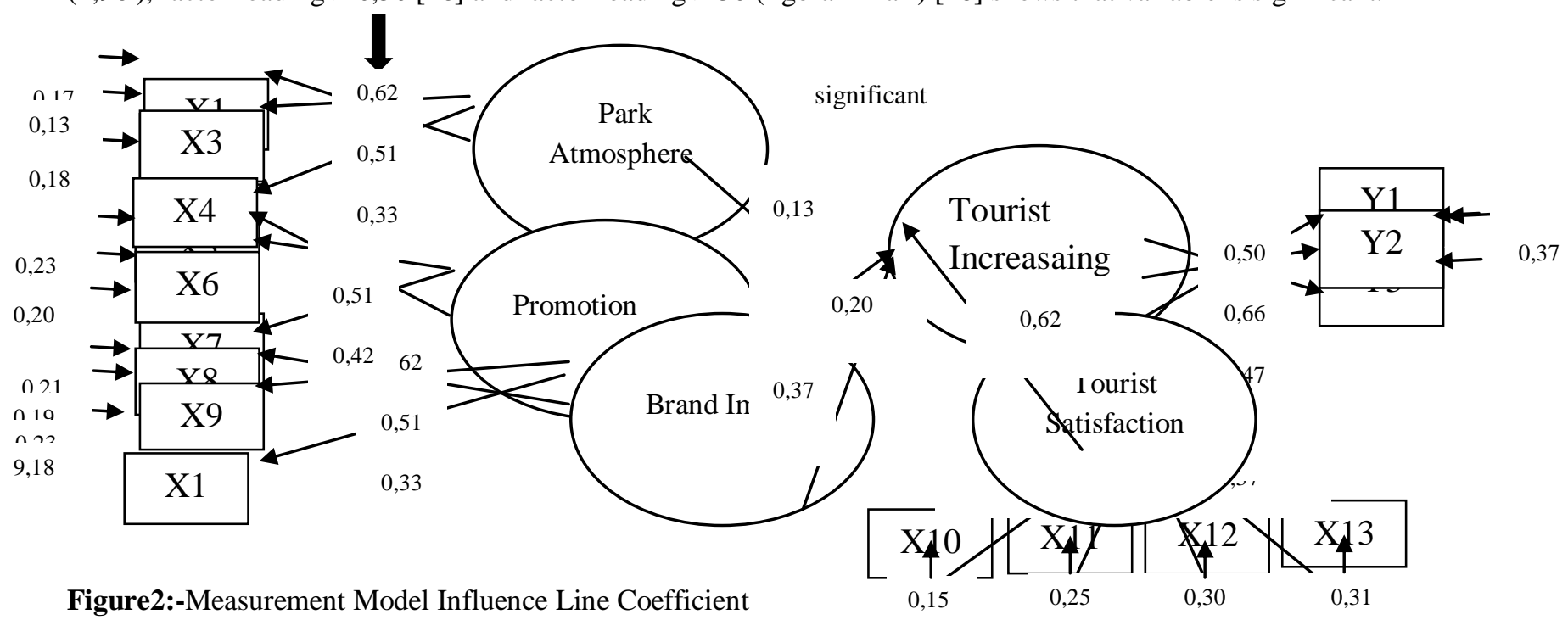

Chi - Square $=470.35$, df $=188, \quad$ P-value $=0.00000, \quad$ RMSEA $=$ v.vu

Source : computer analysis output (2018) 


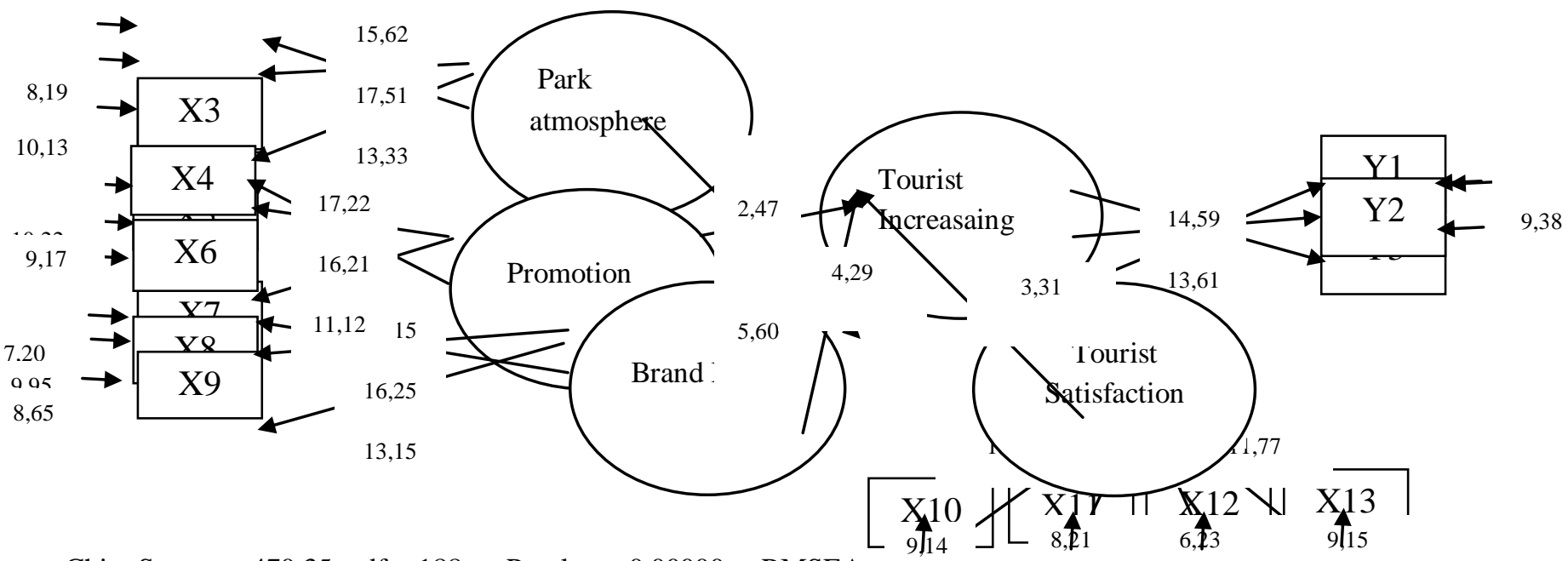

Chi - Square $=470.35, \quad$ df $=188, \quad$ P-value $=0.00000, \quad$ RMSEA $=$

Souce : Computer analysis output (2018)

Figure 3:-T- Count Measurement Model Influence

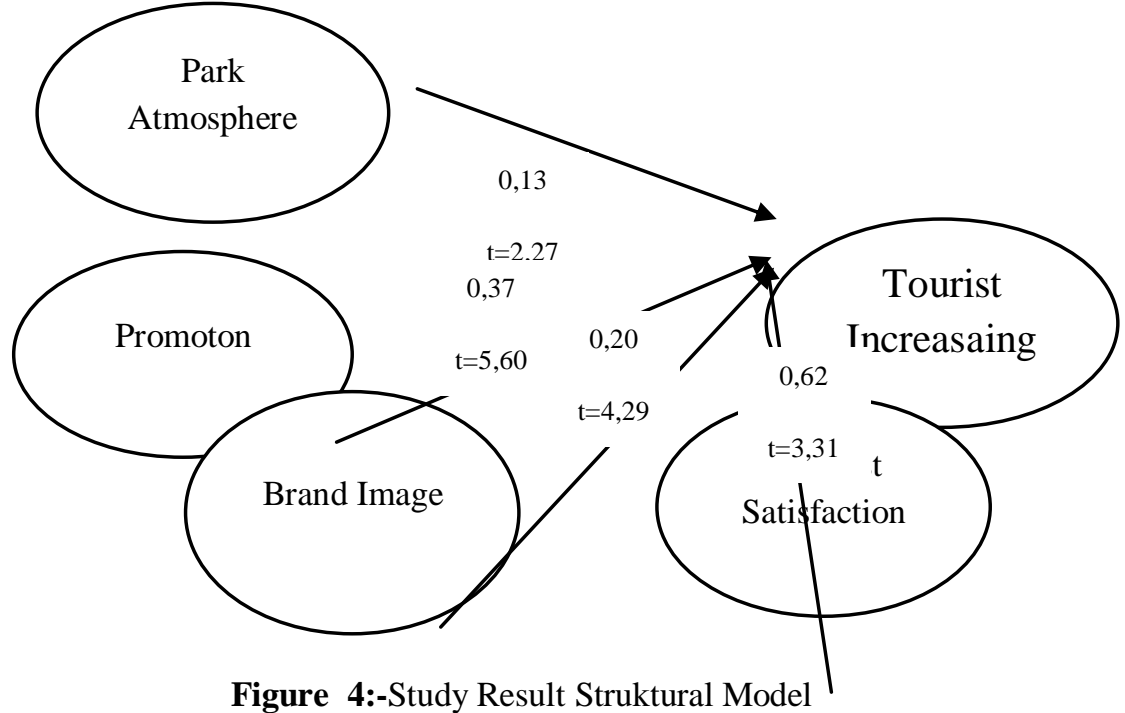

Source :computer analysis output

Tabel2:-Influence of between variables

\begin{tabular}{|l|l|l|}
\hline No & Influence & value \\
\hline 1 & $\begin{array}{l}\text { Park atmosphere } \\
\text { Tourist Increasaing }\end{array}$ & 0,13 \\
\hline 2 & $\begin{array}{l}\text { Promotion } \\
\text { Tourist Increasaing }\end{array}$ & 0,37 \\
\hline 3 & $\begin{array}{l}\text { Brand smage } \\
\text { Tourist Increasaing }\end{array}$ & 0,20 \\
\hline 4 & $\begin{array}{l}\text { Tourist satisfaction } \\
\text { Tourist Increasaing }\end{array}$ & 0,62 \\
\hline
\end{tabular}

Sumber : Hasil Analisis 


\section{Discussion:- \\ H1: \\ Park atmosphere significantly influences the tourist increasing number in Jaya Ancol Art Market. It is mentioned that $\mathrm{t}$ count $>\mathrm{t}$ table that is $2,47>1.96$, so Ho is denied.}

This research uses park atmosphere variable with park situation, emotion and linger. SEM study result shows park atmosphere influences the increasing number of tourists in Jaya Ancol Art Market. Therefore, the situation of the art market should be conceptualized briefly and interestingly so it can influence the emotion of the tourists like eating and drinking in the restaurant and lingering around the art market to shop and enjoy the music.

This research result goes along with the previous research such as Abednego [2] that stated atmosphere influences the shopping motivation, and Fuad [11] states that store atmosphere influences the purchase culture in Gramedia Malang.

\section{H2:}

Promotion is significant toward the increasing number of tourists in Jaya Ancol Art Market. It is mentioned that tcount $>\mathrm{t}$ table that is $5,60>1.96$, so Ho is denied.

This research uses promotion variable with the product differenciation, advertisement frequency and association brand as indicators. SEM research result shows that promotion influences the increasing number of tourists in Jaya Ancol Art Market. Therefore, promotion of the art market should be conceptualized briefly and interestingly by showing product differenciation that is different with others, by showing the ads more often and by having association brand in the mind of the tourists to increase the number of tourists in the art market.

This research result goes along with the previous research such as Geden (1930) that found promotion influences loyalty, and from the research of Josep and Sivakumaran ( 2009) also found sale promotion and brand equity influences the number of tourists.

\section{H3:}

Brand image significantly influences the increasing number of tourists in Jaya Ancol Art Market. It is mentioned that $\mathrm{t}$ count $>\mathrm{t}$ table that is $4,29>1.96$, so Ho is denied.

This resaerch uses brand image variable with attribute, benefit and reputation as the indicators. SEM research result shows brand image influences the increasing number of tourists in Jaya Ancol Art Market. Therefore, brand image with the attribute, benefit and reputation achieved by PT Jaya Ancol from a long time ago should be conceptualized briefly and interestingly so that the increasing tourism in Jaya Ancol is also followed by the increasing number of tourists in the art market.

This research result goes along with some previous researches such as Sara [32]; Mohd et al., [24] found that brand image influences the increasing number of tourists. Muhammad et.al.,[25] this research result shows that brand image is significant to brand loyalty.

\section{H4:}

Tourist satisfaction significantly influences the number of tourists in Jaya Ancol Art Market. It is mentioned that tcount $>$ t table that is $3,31>1.96$, so Ho is denied.

This research uses tourist satisfaction variable with product quality, service quality, price and easiness as the indicators. SEM research result shows that tourist satisfaction influences the increasing number of tourists in art market. Therefore, tourist satisfaction regarding the product quality sold in the art market (paintings, souvenirs, foods, beverages), service quality (attractive, emphaty, responsive personnels, food and beverage attractive and tempting display, interesting look of field court, flower park, and shady trees), affordable price and easy access to the art market should be conceptualized briefly and interestingly so that it will increase the number of tourists in Jaya Ancol Art Market.

This research result goes along with the previous research such as Ghafoor et. al., [14] that found customer satisfaction influences loyalty. Sherman [35] in his research result stated that service quality and tourist satisfaction influence the tourist increasing. 


\section{Research result and Conslution:-}

Descriptive research result describes the respondent evaluation that is negative toward the variable is analyzed and needs to be corrected. The corrections are:

1. Tourist increase, the item needs corrected is recommend to other people.

2. Park Atmosphere, the items need corrected are park attraction and emotional.

3. Promotion, the items need corrected are product differenciation and advertisement frequency.

4. Brand Image, the items need corrected are product quality, service quality, price and easiness.

5. Customer satisfaction, the items corrected are product quality, service quality, price and easiness.

\section{Conclusion :}

The conclusion of this study is hypotheses test based on four emphirical data is proved to be influencing and significant.

\section{Reference:-}

1. Aaker , D (1991) Managing brand equity. New York, NY The Free Press

2. Abednego F. ( 2011) Analisa pengaruhatmospirGeraiterhadappenciptaanemosi, prilakubelanja. FokusEkonomi (FE) Vol 10.

3. Blattberg, R.C. and Neslin S.A. (1990). Sales promotion: Consept,methods and strategies. Englewood Cliff.NJ: Printeice Hall

4. Bohl, P. (2012). The effect of store atmosphere on shopingbehavior, a literature review. Carvinus Marketing Tanulmanyok.

5. Boeselie, P.Hesslink, M. and Wiele, T.V., (2002). Empherical evidence for relationship between customer satisfaction and business performance. Managing Sevice Quality, 12(3) 184-193.

6. Buchari Alma (2004) ManajemenPemasaran Dan PemasaranJasa.Cetakankeenam,

7. Cahndonet.al. , (2008). A benefit congruency framework of sales promotion effectiveness. Journal of Marketing ,64,65-85

8. Chattananon ,Aplisitand Meredith Lawley, (2004). Developing a Model of The TheImpact of Societal Marketing on Coeporate Image. Journal of Service Research, Vol 4 No.2

9. Diamanon, W.D. 1990. Schemas determining the incentive value of sales promotion.Phychology and Marketing, 73 (3), 163-175. Journal of business and psycology

10. Dickson, P. R. and Sawyer, A.G. ( 1990) The faming of sales promotions : An approach to classification. Advances in Customer Research , 17,494-500

11. FuadandMuahammad (2012). Store atmosphere and purchasing behavior . Journal FakultasEkonomi Jambi, Indonesia.

12. Gedenk, K. Nelsin, S.A (1999) .The role promotion in future brand loyalty; its effect on purchase event feedback. Journal of marketing.

13. Gommanset.al ( 2001) . From Band Loyalty To E-Loyalty: A Conseptual Framework. Journal of Economics and Social Research. Indiana Universyty of Pennsylvania, USA .

14. Ghafoor et. al., (2012) .impact of customer satisfaction and brand image on brand loyalty .Progress in Business Innovation And Tehnologi.

15. Hair, Jr. et.al (2010) Mutivariate data analysis, University of Southern Missisippi, Pearson San Fransisco

16. Josep, J.andSivakumaran, B. ( 2009) . The moderating effect of loyalty on the ralatioship of sales promotion and brand equity .Advand in consumer rsearch ,8 263-264.

17. J.Soepranto and NardanLimakrisna ( 2013). Petunjukpenelitianilmiahuntukmenyusun :Skripsi, tesis dan disertasi. Mitra wacana Media, Jakarta, Indonesia

18. Keller , K.L. (1993). Conceptualizing measuring, and managing customer based brand equity . Journal of Marketing (1-22

19. Kotler , P. (1973). Atmoepherics as a marketing toolJournal of marketing, 49(4) 48-64

20. Kotler and Keller (2016) Marketing Manajemen, edisike 13, Darmouth College

21. Kompaskoran (2018) .Ulangtahun PT Jaya Ancolke 40 maksimalkan asset pasar seni. Jakarta Indonesia.

22. Luk, S.T.K. and Yip, L.S.C. (2008) The moderator effect of monetary sales promotion on th relationship between brand trust and purchase behavior. Brand Management 15(6), 452-464.

23. Mohd R, Noor Anida, Nurhidayah, Liu Mei Yan and Low Hwei Ping (2014). Factor Affecting customer Loyalty Towards Airline Industry in Malaysia: An explonatoryAnalysis, International Journal Of Contemporary Research Business Vol 6, No.6 2014 
24. Muhammad Tahir Jan, Kalthom Abdullah and Mustapha HadjSmail (2013). Antecedents of loyalty in the Airline Industry of Malaysia. Busines research, Kuala Lumpur Malaysia 2013

25. Oliver, L.R. ( 1999. When Cusrtomer loyalty ? Journal of Marketing, (33-44)

26. Oliver, R. L. (2007). Satisfaction: A Behavioral Perspective on The Customer. New York: McGraw-Hill.

27. Parasurahman A, Zeithaml VA, Berry LL. A conseptual model of service quality and its implications for future research. Journal of Marketing 1985; (4): 41-50

28. Papatla, P and Krishanamurti, L (1996). Measuring the dynamic effect of promotion on brand choice. Journal of Marketing Research, 33 (1), 20-35.

29. Palazonet.al, (2005). Sales promotion effects on consumer - based brand equity. International Journal of Marketing Research , 47(2)

30. RambatLupiyoadi (2013) ManajemenpemasaranJasa. Salemba. Jakarta

31. Sara Dolnicar, Klaus Grabler, Bettina Grün dan Anna Kulnig (2009). Key drivers of airline loyalty, Tourism Management 2009

32. Sekaran, U. (2006) Research method for business, 6 th edition, John welley and son . Inc USA

33. Setyo Hari Wijanto (2008) Struktural Equation Modeling denganLisrel.Konsep dan tutorial.grahaIlmuYokyakarta, Indonesia

34. Sherman (1997) .Store environment and consumer purchaise behavior: mediating roler of consumer emosions.Physchology and Marketing.

35. Shiffman, L., and Kanuk, L.(2009) . Consumer behavior ( $10^{\text {th }}$ ed). Upper Saddle River, NJ: Prentice Hall

36. Sugiono (2009) .Metodepeneltian dan bisnis, Cetakanke 13 PenerbitAlpabeta, Bandung Indonesia

37. Unal S, Akkus G, Akkus C. (2014) The relationship between the atmosphere, emotion, satisfaction and behavioral in the food beverage enterprises. Gazi University Journal of Tourism Faculty

38. Wakefield, K.L. and Baker, J (1998).Excitement at the mall: Determinant and their behavioral responses , Journal of Applied Business Research (JABR), 24(2). 